\title{
The Application of Communicative Language Teaching to Improve Students' Ability in Speaking
}

\author{
Nurhayati Sitorus
}

Program Studi Pendidikan Bahasa Inggris, Universitas HKBP Nommensen

nurhayatisitorus@uhn.ac.idｈayati.sitorus@gmail.com

\begin{abstract}
The purpose of this study is to investigate students' ability in speaking before and after using Communicative Language Teaching in learning English. The method in this research was experimental quantitative method by using quasi experimental design with one group pretest-posttest model. The design only see students' achievement in speaking before and after using Communicative language Teaching. The object of the research was English Department students. They were randomly selected. The technique of collecting the data was done through observation and the data were gotten from the students when they did oral communication. The instrument in this research was oral test. The data were analyzed by using Lilliefors test, testing homogeneity $F$, and testing hypothesis by using T-test. The result of this study shown that the use of Communicative Language Teaching could improve students' ability in speaking. It was proved from the students' average was higher after using Communicative Language Teaching. The data in this research had normal distribution. Based on data analysis by using T-test was gotten that $t_{\text {count }}=6,59$ at the significant level $\alpha=5 \%$ and $d k(n-1)=(30-1)=29$ was gotten $t_{\text {table }}=1,699$. So, $t_{\text {count }}>t_{\text {table. }}$. It proved that $\mathrm{H}_{\mathrm{o}}$ was rejected, and $\mathrm{H}_{\mathrm{a}}$ was accepted. It's meant that there was a significant difference between students' ability before and after implementing Communicative Language Teaching.
\end{abstract}

Keywords: Communicative Language Teaching, Method, Speaking

\section{Introduction}

Language is a tool that human used to communicate one each other. Communication can be done orally or written. Communication that human do orally is called speaking. Speaking is one of the skills in English. Through speaking, human can deliver their ideas, feeling or opinion to the listeners.

In learning English, speaking is a difficult thing for students, especially for new students that take English Department. It is caused that English is second language for them. In teaching learning English, the students faced many difficulties and problems especially in speaking. First, the students were difficult to pronounce the words well. Second, the students did not have enough vocabularies, so they were not able to build a complete sentence when they spoke to the listeners. That's why they were not able to do speaking in English full. They tended to mix their language, Indonesian and English or just speak in mother language, namely Indonesian. Third, they were not self-confidence to speak in English with their friends and their educator. It's caused They were afraid. The fourth, when the educator gave them a task, they were not able to do the task directly. They tended to write first, then memorize their answer. Then, deliver the answer orally. And the last, the grammar and structure that they used when they spoke was wrong. 
The students' difficulties and students' problems in learning English, especially in speaking can be solved by using Communicative Language Teaching (CLT). Communicative Language Teaching aims broadly to apply the theoretical perspective of the Communicative Approach (CA) by making communicative competence goal of language teaching and by acknowledging the interdependence of language and communication (Larsen, 2004:121). By using Communicative Language Teaching, the students' ability in speaking will be improved. It's caused in the classroom; the educator uses target language (English) in teaching. And if the students do not understand, the educator can use the mother language. But as possible the educator and the students must avoid using mother language. Here, the educator has function as an adviser and a guide. So, when the students do errors in learning English, the educator will tell, guide them and correct their errors at the last. They also give advice and motivation to motivate them to learn English. In this case, the educator also can use the realia to help the students understand about the matery, especially for new students or beginner students. In other side, some techniques that used in learning English like games and role play make the students to communicative effectively (Larsen, 2004:132-134).

Therefore, a research entitled "The Application of Communicative Language Teaching to Improve Students' Ability in Speaking". Through this research is hoped there is significant improvement after using Communicative Language Teaching in speaking.

\section{Method}

The method of the research was experimental quantitative research by using quasi experimental design with one group pretest-posttest model. The sample of the research was English department students. It consisted of 30 students. They took randomly. The technique of collecting data was done through observation. The data source was gotten from students' utterances when they did oral communication.

The instrument of the research was oral test. There were six components or aspects that the writer used to asses students' ability in speaking, namely grammar, vocabulary, comprehension, fluency, pronunciation, and task (Brown, 2001-172-173). To analyses the data, the writer used Lilliefors normality test, testing homogeneity $F$, and testing hypothesis by using T-test.

\section{Results}

Based on the data analysis of the research, the findings of the research are:

1. The students' ability before implementing the Communicative Language Teaching is enough and the average of students' achievement was 58,67.

2. The students' ability after implementing the Communicative Language Teaching was good and the average of students' achievement was 73,67.

3. The data of the students' ability before and after implementing the Communicative Language Teaching were on normal distribution, namely at the level $\alpha=5 \%$ and $\mathrm{N}=30$ is gotten $L$ count $<L$ table namely $0,1298<0,161$ (before treatment) and $L_{0}<L$ table namely $0,1413<0,161$ (after treatment).

4. The homogeneity test by using variance test was obtained $F$ count $=0,668$ and $F$ table $=42,557$ so, $\mathrm{F}_{\text {count }}<\mathrm{F}$ table so the variance of the sample came from homogenous population.

5. By using T-test was obtained $t$ count $=6,59$ at significant level $5 \% d f=(n-1)=30-1=29$ and $t$ table $=1,699$ so $t_{\text {count }}>t_{\text {table }}=6,59>1,699$. It could be concluded that there was a significant 
difference between the students' ability in speaking before implementing Communicative Language Teaching and after implementing Communicative Language Teaching.

\section{Discussion}

Students' ability improved after using Communicative Language Teaching. It could be seen from the mean of students' achievement before and after using Communicative Language Teaching, namely 58,67 to be 73,67 . It proved that the use of Communicative Language Teaching could improve the students' ability in speaking.

Based on the normality and homogeneity test, the data before and after doing treatment has normal distribution and has same variance. And based on data analysis by using T-test was gotten that $\mathrm{t}_{\text {count }}=6,59$ at the significant level $\alpha=5 \%$ and $\mathrm{dk}(\mathrm{n}-1)=(30-1)=29$ was gotten $t_{\text {table }}=1,699$. So, $t_{\text {count }}>t_{\text {table. }}$ It proved that $H_{0}$ was rejected, and $H_{a}$ was accepted. It meant that there was a significant difference between students' ability before and after implementing Communicative Language Teaching.

Based on the result that has been described above that Communicative Language Teaching is a teaching method that can improve students' ability in speaking by using English as introduction language. Here, the educator uses English when s/he explains the lesson. And the educator has function to give advise and suggestion to the students. The educator also must motivate in teaching English especially when they do communication.

In Communicative Language Teaching, almost all activities are done with a communicative intent. Here, the students use the language a great deal through communicative activities when they do games, role play, and etc. in learning English in the classroom. That's why it can make the students fun to study English and It can improve students' ability in speaking.

\section{Conclusion}

Based on the finding of the research, it can be concluded that:

1. The students' ability in speaking before implementing Communicative Language Teaching is inadequate.

2. The students' ability in speaking after implementing Communicative Language Teaching is good.

3. There is a significant difference between students' ability before and after implementing Communicative Language Teaching.

From the result of the research was known that Communicative Language Teaching is very good to be implemented in speaking.

\section{Acknowledgment}

The writer would like to say thank to University of HKBP Nommensen for supporting to complete the research.

\section{References}

Arikunto, S. (2005). Manajemen Penelitian. Jakarta: Rineka Cipta.

Astuti. E. D. (2010). Meningkatkan kemampuan Percakapan Bahasa Inggris Siswa dengan Model Make a Match pada Siswa Tunarungu Wicara dan Tunagrahita VII SMPLB. JASSI_Anakku, 9(1), 66-75. 
Badan Pengembangan dan Pembinaan Bahasa. (2005). Kamus Besar Bahasa Indonesia (KBBI). Jakarta: Balai Pustaka.

Brown. (2001). Principle of Language Learning and Teaching. New York: Prentice Hall.

Brown. (2004). Language Assesment Principles and Clasroom Practices. New York: Pearson Education.

Caganaga. (2014). The Effect of Communicative Approach on Learners Foreign Language Profiency Levels by Using The Need Analysis in English For Specific Purposes Classes. International Online Journal of Education and Teaching (IOJET), 1(2), 91107.

Richard, J. \& Rodgers T. (2007). Approaches and Methods in Language Teaching. Cambridge: Cambridge University Press.

Larsen. (2004). Techniques and Principles in Language Teaching. Oxford: Oxford University Press.

Stoner. G. M. (2009). Effectively Communicating With Visual Aids. Mattstoner. Net.

Sudjana. (2005). Metoda Statistika. Bandung: Tarsito.

Sudijono, A. (2007). Pengantar Statistik Pendidikan. Jakarta: Raja Grafindo Persada.

Sugiyono. (2012). Metode Penelitian Kuantitatif, Kualitatif, dan R \& D. Bandung: Alfabeta

Uno, H. B. (2009). Model Pembelajaran. Jakarta: Bumi Aksara

Ur, P. (1996). A Course in Language Teaching: Practice and Theory. Cambridge: Cambridge University Press.

Yasin. (2017). Communicative Language Teaching for Teaching Speaking. English Education Journal (EJJ), 8(3), 322-337. 